\title{
Multinationals and labour: a review of contemporary issues and concerns
}

\author{
Peter Enderwick*
}

In the past ten years there has been comparatively little research on the topic of multinational enterprises (MNEs) and labour despite the continuing importance of such issues and the emergence of new concerns. This paper discusses a number of current concerns and summarises relevant evidence. In the late 1980s the major issues relate to employment stability and the introduction of innovative labour practices. A number of very recent concerns include service sector MNEs, safety issues, racism and the problems of women workers within MNEs.

\section{Introduction}

In the late 1970 s it was possible to enumerate the major issues confronting labour in its dealings with multinational enterprises (MNEs) as employment effects, particularly the displacement of jobs in the parent nation as overseas investment occurred, and the implications of comparative studies of the effects of ownership nationality on wage levels, industrial conflict and industrial relations practices. Labour responses to the challenge of the MNE emphasized the need to acquire information, to pool and exchange information across national borders and to mobilise political support for the introduction of controls over the conduct of MNEs (Enderwick, 1979). The achievement of transnational bargaining was seen by many as an inevitable future development (Gennard, 1972).

Ten years on, labour has made very little progress in offering an effective response. Indeed, interest in these issues has declined significantly. The recessionary conditions of recent years have had the twofold effect of highlighting the employment and labour relations decisions of all firms, and particularly large firms, irrespective of their multinationality, and at the same encouraging national responses to the problem of ensuring continued competitiveness in world markets. For major source and host nations like the USA and the UK this has implied a desire to attract inward investment, particularly strongly competitive Japanese firms, the tolerance of outward investment as parent nation enterprises seek to retain overseas markets, and at the same time the adoption and diffusion of innovative management methods pioneered in many cases by leading MNEs. The weakness of organised labour has meant little effective opposition to such changes, indeed the extent and speed of change has been applauded by national governments as an indication of growing labour market realism (Clarke, 1987).

The intention of this paper is to survey a number of current labour concerns with 
MNEs and to summarise the relevant evidence. Coverage is restricted to the advanced industrial economies. For a useful introduction to labour concerns in developing countries the reader is refered to Jenkins (1987) and the references contained therein.

In the last ten years MNEs have considerably strengthened their role in global industries. MNEs from North America, Japan and Western Europe enjoy an unassailable position in the most research intensive sectors where sales and employment growth prospects have been strongest in recent years. Similarly, service industries are becoming increasingly multinational in their orientation (Enderwick 1989). The surge of management initiatives in areas of labour flexibility, single union agreements and restrictions on strike activity have attracted a great deal of research interest. In many cases these innovations have been developed within large MNEs. For these reasons an examination of the implications for labour is timely.

\section{Employment issues in multinational enterprises}

Patterns of employment change within multinational enterprises are of considerable significance because of the importance of MNEs in the world economy. There are in excess of 10,000 MNEs operating more than 90,000 affiliates worldwide. However, a small number, (some 500) account for around 80 percent of all international production (Stopford and Dunning, 1983). These firms employed directly some 25 million in manufacturing and perhaps a further 10 million in service industries in the mid-1970s (ILO, 1981). Understanding their employment strategies is clearly important.

The export of jobs

Between 1971 and 1980 the world's leading MNEs increased their total employment by a modest 30 percent, a rate of growth much lower than that achieved in sales, net earnings or assets. Overseas employment grew more rapidly, nearly doubling in the period to around 5.7 million (United Nations, 1983). On almost any measure these companies became increasingly international in their orientation. In the late 1970s there were significant differences between nations in both the rate and pattern of employment change (Enderwick, 1988). While most countries experienced only very modest employment growth within the domestic operations of their MNEs, this was combined in some cases with very rapid growth in overseas employment. MNEs from countries like Italy and the Netherlands contracted employment both at home and overseas. UK-based MNEs were unique in displaying a pattern of heavy domestic employment reduction with rapid overseas expansion.

The pattern of employment change revealed in the above-mentioned study throws considerable doubt on the entrenched assumption of many labour groups that MNEs are actively exporting jobs. With the exception of the UK there were comparatively few examples of industries increasing overseas employment while reducing domestic employment. Excluding the UK, only 10.9 percent of domestic employment losses occurred in industries simultaneously expanding their overseas employment. A uniform pattern was apparent in the case of domestic job creation where almost 100 percent of domestic employment growth was accounted for by industries simultaneously expandin their overseas workforces. These patterns suggest the complementarity of domestic and overseas production.

In the two cases highlighted above, the assumption of a high degree of substitutability between domestic production (and employment) and exporting, and overseas production breaks down. In the first case (declining domestic and overseas employment) domestic employment decline occurs because of decreasing competitiveness, not as a result of multinationality per se. In the second case (declining domestic, expanding overseas employment), if increasing overseas production (as measured by employment change) is a reflection of competitive strength, then its coincidence with domestic contraction may be interpreted as a sign of shifting locational preference. The important implication for labour is in understanding the sources of declines in competitiveness and/or locationa advantage. The strategy focus must shift from that of direct pressure on management to resist relocation (or indirect pressure through government restrictions on capital mobility) to one of tackling the causes of decline. A good example is provided by the decreasing labour cost competitiveness of many US producers. In an attempt to limit any further widening of international wage differences US labour has become an active (albeit not always willing) participant in wage concession bargains. In 198553 percent of manufacturing employees who were covered by collective bargaining agreements suffered a wage freeze for at least one year. A further 72,000 workers agreed to wage cuts overaging almost 9 percent (Linsenmayer, 1986).

\section{Employment instability}

Within the developed nations concern over the issue of employment instability has been fuelled by the growing body of research which has examined the characteristics of socalled branch plants (additional capacity concentrating on assembly/ manufacturing operations) which are a widely used operating form for MNE subsidiaries. There does appear to be a strong relationship between employment instability and external ownership, particularly within the peripheral regions (Enderwick, 1982; 1990).

External ownership is associated with employment instability for a number of reasons. First, the employment record of a plant may depend upon its role and function within wider corporate framework (Young, Hood and Hamill, 1988). Employment prospects may be unrelated to immediate conditions or performance, and responsibility for employment decisions may reside outside the host region (or nation).

A second disadvantage associated with multiplant, multinational enterprise is their tendency to locate standardised products in the later stages of their life cycle in the branch plants of peripheral areas. This has implications for both the quantity and quality of employment creation. Such plants tend to be characterised by a high degree of capital intensity and the creation of relatively low skilled jobs. Their disadvantages are readily apparent. The generous financial assistance (and often continuing subsidisation) necessary to attract them encourages projects which might, in the absence of assistance, be commercially non-viable; it accelerates plant write-offs and the scrapping of capital producing standard products in the maturity and saturation phases of their life cycle; encourages excessive capital intensity in economies usually characterised by a chronic over supply of labour; and adds little to the stock of industrial training and skills formation.

Labour responses to the problem of employment instability have shifted perceptibly from the direct to the indirect. The principal direct strategies have been the development, by workers, for companies in difficulties, of alternative business plans. The best known example is probably the Lucas (UK) case. In anticipation of likely defence expenditure cuts the combine committee of the Aerospace division prepared an extensive business plan focusing on socially useful production but this never achieved any real acceptance (Coates, 1978).

A second strategy has been the employee-financed buyout. Management buyouts have increased dramatically in recent years and there have been a number of notable successes (Coyne, 1986). There has also been growing interest in the concept of labour-managed firms but their development seems to be confined to smaller-scale enterprises (Bradley, 1980)

The limited success of these initiatives has fuelled pressure for more indirect strategies concerned with reducing and managing the problem of employment instability. More intensive screening of inward investment could be useful in reducing the number of accepted projects likely to fail.

The experience of Northern Ireland with commercially doubtful (De Lorean) and 
technologically innovative (Lear Fan) projects suggests that in many cases a high probability of failure can be foreseen. Similarly, governments should understand the impact of subsidies and incentives on employment creation and maintenance. For example, the provision of finance and information to overseas-based firms serves to erode the inherent advantages enjoyed by indigenous firms and can accelerate rationalisation in this sector. More creative strategies to tackle high levels of plant closure and contraction include 'exit barrier' policies which seek to tie in existing plants to the local economy. These assume a variety of forms including favourable tax structures, supportive infrastructure investments and tailored manpower and training schemes. However, the experience of the Republic of Ireland's largely foreign-owned software industry suggests that in isolation such policies may not be enough. A small host market makes export marketing essential. The high costs of this put a severe strain on the working capital of small software companies. Their continuing health may require considerable financial and marketing assistance. Performance requirements, particularly those specifying some percentage of locally sourced inputs, can have a similar impact in orientating investors towards the local or regional economy.

Two increasingly widely used instruments involve state intervention in the operations of foreign-owned firms. The Northern Ireland Industrial Development Board was closely involved with Du Pont's decision to extend the life cycle of its long established plant by the introduction of Kevlar production. This suggests that the monitoring of product life cycles within existing investors and the provision of the necessary assistance in extending plant life cycles can be beneficial. A related strategy involves attempts to attract higherorder functions ( $\mathrm{R} \& \mathrm{D}$, design, marketing) to complement the production facilities characteristic of branch plant operations. Nissan (UK)'s recent decision to establish a design centre at its Sunderland, England production site is an example of such thinking.

In an attempt to increase employee involvement in the management of plant closure and contraction a number of initiatives in information disclosure and consultation have occurred.

Within the European Community legislation has been concerned with both employment protection and information disclosure. Two directives, introduced in 1975 and 1977, sought to reconcile national differences in member countries' legislation regarding company responsibilities and employee rights in the event of mass dismissals or changes in company ownership or control.

However, dissatisfaction with these directives, particularly the fact that they do not give employees sufficient powers to influence the decision-making process, resulted in calls for more far-reaching provisions. The two major proposals were the Fifth Directive on employee participation and the Vredeling Directive on employee consultation and information rights (Latta and Bellace, 1983). Opposition to both these proposals has been considerable and has come from powerful MNEs and employer groups both within the European Community, e.g. Britain, and outside, e.g. the USA and Japan. National governments have also voiced considerable reservations. This opposition has been founded on the detrimental impact of increased regulation on company costs and competitive flexibility.

While these initiatives have been stalled at the regional level a number of developments have occurred within member countries like France. The difficult economic conditions of the 1980s have increased the willingness of major employers to inform and consult employee groups; often in an attempt to obtain concessions. In France a unique set of circumstances, including politically-sympathetic managements and politicians, have resulted in important consultative arrangements within a number of large MNE (Northrup, Campbell and Slowinski, 1988). One lesson of these agreements and the recent American experience (Kassalow, 1988) is that employees are more likely to obtain information and consultative rights when they are prepared to offer something tangible in return (wage freezes, wage cuts, relaxation of work rules etc.), than where such rights are simply encoded in legislation.

\section{Multinational enterprises and innovative labour practices}

The association of foreign-owned firms with innovative labour practices is a longstanding one. In the late 1950s and early 1960s US MNEs in Europe pioneered the practice of productivity bargaining (where wage increases were tied to improvements in performance or a relaxation of union restrictions). They were also at the forefront in tackling problems such as the high level of unconstitutional disputes experienced in the UK in this period (Gennard, 1972). More recently, Japanese MNEs operating in Europe, the United States, Australia and New Zealand have introduced a variety of novel practices including single union agreements, no-strike agreements and flexible labour practices (Enderwick, 1985).

\section{Characteristics of innovative labour practices}

These examples share four characteristics. The first is the fact that these waves of innovation have been associated with the prevailing dominant managerial paradigm. In the late 1950s and early 1960s the superior performance of US firms (and the US economy) suggested that these firms were doing something different (or better) than their competitors. The study of their management methods provided detailed examples of individual practices and the inference that such practices could be adopted and implemented in a partial or selective form. This argument was just as true thirty years ago for US management practices (short-term budgetary control management, top down decisionmaking, performance-based reward systems) as it is today for Japanese type practices (consensus decision-making, JIT-manufacturing, quality circles, harmonisation of terms and conditions). The competitive strength of Japanese enterprises means that interest is now firmly focused on their management practices. Ironically, this interest is particularly strong in the USA (Sethi, Namiki and Swanson, 1984).

The second characteristic is that the transplant of managerial practices by foreignowned firms is always selective. Japanese management practice in Japan is associated with a number of features (lifetime employment, seniority-based payment schemes, company-based welfare systems) which are rarely in evidence in overseas host nations (Choy and Jain, 1987; Jain, 1985; Matsuura, 1984; Pang and Oliver, 1988; White and Trevor, 1983). The companies involved cite this as evidence of their sensitivity and adaptation to host nation conditions.

Third, a notable feature of practices that are transferred is that they have an important bearing on what might be seen as major weaknesses or deficiencies in the host nation business system. For example, during the 1960s and 1970s a number of large US MNEs tackled through various initiatives the problem of frequent, short stoppages characteristic of British industrial relations in this period. The competitive pressure of recent times which has prompted a search for greater flexibility in the workplace has coincided with the moves of many Japanese MNEs to rationalise the prevailing pattern of multi-union representation characteristic of manufacturing industries in a number of countries.

Inward investment has also been associated with considerable improvements in the quality of manufacture (Sawers, 1986). Similar developments have occurred in the United States with the Saturn agreement for example. Nissan's experience in New Zealand provides further confirmation of such benefits. Ten months after signing a new work agreement with the engineering union Nissan claims that the quality of locally assembled vehicles now matches that of Japanese built models. They are the only New Zealand assembler able to offer a $60,000 \mathrm{~km} / 3$ year warranty on all cars. The expansion of sales apparently attributable to the improvement in quality has resulted in the creation of an additional 50 jobs.

The fourth feature on innovative labour practices is a tendency for their generally 
uncritical acclaim. Since they are usually associated with a superior managerial paradigm their adoption and diffusion is widely urged. This attitude is most clearly displayed by politicians and management writers in the host economy. A worrying aspect of this politicians and mactices which are intoductices is, rarely forming a coherent package of policies. In many cases the practices are introduced into a totally alien environment (typically much more adversarial) or are in response to a crisis situation. Neither case is conducive to success (Ackroyd, et al. 1988).

The ramifications of such innovations are rarely explored. A good example is provided by the current interest in just-in-time (JIT) practices. Obtaining the full benefits of JIT production requires the successful negotiation of a disruption free environment both within the company and its suppliers (Graham, 1988). The recent experience of Ford in the UK the company and its suppliers (Graham, 1988). The recent experience of Ford in the UK where a pay related strike led to layoffs in other plants within three days is indicative of
what can happen. Ford's move towards minimal inventory levels and a shift away from what can happen. Ford's move towards minimal inventory levels and a shift away from its strat extrplier, supplier, led to shorlages within three days. Lucas is anther (Tumbull, 1986). The company which has embraced Japanese style production methods (Turnbull, 1986). The financial savings of JIT are potentially so great that many producers appear willing to pay the price of increased vulnerability to industrial action. Ford in the US estimates that its traditional inventory management process ties up around $\$ 8.5$ billion of capital; some ten times the amount Nissan and Toyota have tied up. The major Japanese producers have managed to establish a much more favourable environment for JIT production where strike-free agreements are widespread and suppliers are typically small firms, the majority non-unionised.

\section{Labour flexibility}

The focus of innovative practices in the 1980s has been on increasing labour force flexibility. Flexibility is essential to Japanese producers whose business philosophy is based performance. The based on achieving a continuous improvement in productive performance. The implementation of change is greatly facilitated by resource flexibility (Reitsperger, 1986). The potential pecuniary benefits of flexibility are also considerable. Estimates for the UK suggest that a traditionally organised manufacturing plant could, with a complete adoption of flexible organisation and practices, reduce manning levels by up to 30 p

machine efficiencies by 15 percent and machine speeds by $20-65$ percent.

The new style agreements concluded principally by large multinational producers have a number of common features (Rico, 1987). The first is a preference for single-union recognition. Studies for the UK (Buckley and Enderwick, 1985; Millward and Stevens, 1986) confirm the view that foreign-owned firms are less likely to bargain through the complex multi-union structures still common in the UK. Some incoming investors are clearly ant-uion. The EETPU, a union which has been closely identified with many of ent Committee of a denial of full union recognition even where the union has voluntarily agreed to a strike-free condition. The benefits of single union representation can b considerable. Nissan (UK), in extending sole recognition rights to the AUEW, enjoyed considerable advantage over the then Austin Rover which negotiated with 13 unions in 5 company-level bargaining groups.

A second element is single status or a harmonisation of working conditions for different employee groups. Nissan (UK) provides a good example with equality in hours of work, holidays, overtime premiums, pensions and sickness pay for all employees. The almost 50 percent decline in average absenteeism which has occurred within Nissan New Zealand in the last year has allowed the company to consider the phasing out of clockcards. The elimination of pay deductions for manual workers for occasional lateness represents a considerable move towards unification of conditions for manual and nonmanual workers.

A third characteristic is the existence of a no-strike clause often in combination with some sort of binding arbitration. No-strike agreements have received a great deal of publicity (Bassett, 1986). International Labour Reports (1986) suggests that there are perhaps 20 UK plants with around 20,000 employees operating under no-strike agreements.

While not every new style agreement contains all these elements (Fox, 1987) most are supported by considerable investments in training (Dunning, 1986; Pang and Oliver, 1987), extensive and intensive screening of new employees and a considerable commitment of resources to the personnel function (Buckley and Enderwick, 1985; Dunning, 1986; Millward and Stevens, 1986; Purcell et al. 1987).

Impact of innovative labour practices

The impact of practices of this type on a country's industrial relations system depends on a number of factors. The direct impact (Ackroyd et al., 1988) is determined by the number of investing firms, their size and spatial concentration. Estimates of the number of Japanese manufacturing establishments in the UK suggest that there are in excess of 50 of Japanese manufacturing establishments in the UK suggest that there are in excess of 50 sales accounting for only 0.4 percent of all foreign-owned subsidiaries in the UK and 0.08 percent of all manufacturing plants. Japanese firms are typically very small. One study of 200 Japanese firms reported that 81.3 percent of respondents employed 50 or less. The diffusion of Japanese management practices through linkages with suppliers has also been limited. However, in areas like South Wales where the majority of Japanese firms in the electronics industry are to be found, generally producing standardised items, there is a fairly high degree of local sourcing (Morris, 1988). In the Nissan (UK) car plant, where there is pressure to increase local sourcing, some 27 British suppliers have obtained contracts but the company has reported major problems over the quality of local supplies. Several British companies have formed joint ventures with Japanese component suppliers and the number of Japanese suppliers attracted to the UK is increasing. In the US there are now 232 component firms supplying the 6 major Japanese vehicle producers. The influence of overseas practices may be even more nebulous. The attractiveness of the Shipping Corporation to an overseas buyer was undoubtedly enhanced by the reflagging exercise and the subsequent impact on labour costs and terms and conditions.

Diffusion is encouraged by a number of other factors. The marked geographical concentration of Japanese suppliers, often within the less prosperous areas of a country, means that the local impact could be considerable. The low average age of 'employees within Japanese firms may assist the spread of the Japanese work ethic if through their higher than average rate of labour turnover such employees carry these values and attitudes to a wider audience. The limited evidence suggests that labour turnover in Japanese companies is similar to that found elsewhere in British manufacturing (Pang and Oliver, 1988; White and Trevor, 1983).

A similar impetus to diffusion may result from the very high rejection rates of potential employees displayed by Japanese firms. Nissan (UK) in seeking to fill 22 supervisory posts interviewed 200 out of a total of 3,500 applicants. There were around 50 applicants for every production job. The experience of rejection might alert a very large potential workforce to the characteristics sought by innovating employers.

Finally, the attraction of the assisted areas of the enlarged European Community and member governments' willingness to financially underwrite large elements of the total investment package mean that such investments are likely to increase. The British government's willingness to fund up to 25 percent of the $\$ 600$ million Nissan (UK) investment was founded on a belief that the money is well spent when one considers the industrial relations demonstration effect. This may be a significant consideration since 
some estimates suggest that the net employment effects of the Nissan entry could be ( negative as jobs are lost within less efficient competitors. Ford (UK) 1987).

Evidence on the absorption of Japanese-type management practices in the UK suggests that to date the impact has been limited. The primary area of impact has been within that leading UK-based MNEs. A number of firms have adopted of were the changes have been not always been successful or long lived (Smith, 1988). Werox) the apparent benefits more comprehensive and carefully planned (Lucas, Jaguar, Xerox) the apparent benefits appear significant (Giles, 1988; Turnbull, 1986). Progress has been slower in a numbe of cases such as Ford where attempts to improve quality, limit job demarcations, restructure the role of foremen and move towards harmonisation of conditions for different groups of workers have met considerable opposition.

\section{Durability of innovative labour practices}

Some doubt has been cast on the likely extent to which these practices will persis (Rico, 1987). Many of the innovative Japanese producers are small, single product firm which have been established on greenfield sites. Whether the practices survive rapid which hove growth or the with style deals have been corch technical employees or those branch plant type facilies cond products produced with a large percentage of unskilled, often female labour. Whethe firms with a more heterogeneous product and employment mix can implement similar practices remains to be seen

Rico (1987) also questions whether these innovatory practices will survive an upturn - Rico (1n which changes have been introduced in many cases in eccnos does suggest an element of opportunistic behaviour. In which impeded which impeded the conclusion of a single union deal at a new Coca-Cola bottling plant, led to the loss to Spain of a new Ford component factory and culminated in the withdrawa of the EEPTU from the TUC are indicative of the conflicting perspectives. It is of the EEPT from the opportunity to exploit acts of omission on the part of host country producers rather the opportunity to exploit acts of omissionible management paradigm (Dunning, 1986; than being in

\section{New issues in multinational labour relations}

The past ten years has also seen the emergence of a number of new issues in the The most important have been the growth of relationship between MNEs in non-manufacturing, particulacism at the workplace and the position of women workers within MNEs.

\section{MNE employment in the service sector}

Recent years have witnessed a very considerable growth in employment within the ector. At the same time a number of service industries are rapidly internationalising and employment is becoming increasingly concentrated within a small internationalising and empery large service MNEs (Enderwick, 1989). Traditionally, many service in of unionisation and poor wages and working conditions. Recent studies suggest that the penetration of MNEs into these industries has done little to alter such conditions. Within the UK contract cleaning industry, for example, the top nine firms account for almost half the 1 employment and 45 percent of market share (British Business, 1988). Cleaning, like parts of the fast-food industry, displays below average wages, high levels of labour turnover and limited union organisation (Lamb and Percy, 1987; Landor, 1986). Service industries are likely to become an increasingly important area for analysis of the relationship between MNEs and labour.

Employee safety and social responsibility

Since the Bhopal tragedy which killed more than 3000 and injured some 200,000 there has been growing concern about the health and safety provisions of MNEs and thei assumption of social responsibility, particularly in the developing countries.

A recent ILO study found that most MNE managers felt that health and safety agreements were entirely a management responsibility and should not form part of the collective bargaining process (ILO, 1984). This suggests the possibility of variation between enterprises and establishments in such provisions. Although the report indicated the above average performance of MNEs in the area of health and safety, their overrepresentation in possibly hazardous industries like chemicals means that the potentia costs of inadequate provisions and controls are enormous and may necessitate more stringent regulation. Similar concerns are felt in the developed countries as illustrated, fo example, by the recent decision to reopen the investigation of the ICI fire in New Zealand which resulted in the death of a firefighter. With growing concern and action over industrial accidents and pollution this is one area where further research is required.

\section{Racism at the workplace}

In the same way that policy concern over health and safety issues is increasing, the growth of anti-discrimination legislation is highlighting the position of large-scale employers like MNEs. In Britain, an investigation of the Canadian multinational Massey-Ferguson found that in a city where about 10 percent of the population are black the firm's workforce percentage was only 0.15 . Through a policy of above average wage levels vacancies were readily filled through the network of existing employees, perpetuating the imbalance. When the British-based Midland Bank first attempted to acquire the US Crocker Bank a challenge by US black and hispanic groups led to a claim There is growing concern over the practices of Japanese MNEs. The inferior position of Koreans living in Japan has increased interest in the overseas employment practices of Japanese firms. In the United States a number of leading Japanese MNEs, including Hitachi and Honda, have faced court action over practices which discriminate against women and minority groups. A recently published study of Japanese automobile plants in the US, while not alleging overt discrimination, does suggest considerable inequality in employment composition and the possibility that avoidance of areas with a significant black population is one factor in the site location decision (Cole and Deskins 1988). While MNEs may be no worse than many indigenous employers in such matters, their size and high profile means that they need to be particularly careful in the monitoring of racial composition and in the implementation of potentially discriminatory practices.

\section{MNEs and women workers}

There are two major areas of concern regarding the impact of MNEs on female workers. The first is the relatively well researched question of the experience of wome manual workers within multinational affiliates, particulary those located in developin 
countries. The second concerns the problems of women executives within MNEs, a topic which has received much less research attention.

One estimate suggests that MNE direct employment of women workers in developing conct countries amounted to slightly over 1 million in 1980. Indirect employment might add a further half million to this (Lim, 1985). The majority of female workers are in the industrial sector and are typically young, single and new-entrants to the labour force They are employed predominantly in unskilled and semi-skilled jobs in labour-intensive industries where traditionally perceived female traits (manual dexterity, willingness to industries whit trasks) are valued. These occupations generally display low perform repetitive

nion organisation. One view is that, on balance, these females benefit from the operations of MNEs.
Compared to indigenous firms they offer above average wages and conditions and, in countries like Singapore, the entry of overseas firms by accentuating labour shortages has increased the employment opportunities of those from non-traditional groups, including women in white-collar occupations (Lim, 1985).

The opposing view is that MNE employment only serves to reinforce the subordinate postion of we repressive policies position of women in their society. This occurs because of governments devise to support incoming firms (see Section IV), the use of corporate practices like beauty pageants which transfer Western views of female docility and the problems of employment instability (Ward, 1988). The minimal level of skills typically acquired within MNEs and the specifity of skills means that these are rarely transferable in the event of employment decline which has occurred in countries like Jamaica, Haiti an the ef turnover mean that more than million females may have passed through MNansferability of skills provided has been very low.

The problems of women executives within MNEs are really the problems of women exectives in any company, including sex role stereotyping and occupational sex labeling. In the multinational context additional difficulties arise. The principal ones are obtaining acceptance in a variety of cultures, many of them extremely hostile to women executives, and overcoming the obstacles to international mobility (Izraeli, Banai and Zeira, 1980). These are areas where considerably more research is needed.

\section{Conclusions}

The preceding discussion suggests a number of conclusions. The first is the decline in interest in the area of MNEs and labour which has occurred over the last ten years. The remendous problems faced by organised labour in the recessionary conditions of recent tremendous problems faced by organised labour in the at the expense of international years has meant a concentration on domestic issues at the expense of international concerns. Ironically, this period has witnessed a considerable growth in the economic power and global spread of international companies. The relative pow

labour vis-a-vis the MNE appears to have declined in the past ten years.

Second, the weakness of labour has increased the attractiveness of indirect responses to the power of multinational firms. The continuing calls for codes of conduct, legislation the prowth of 'corporate campaigns' launched against problem firms have been a feature of recent years. In the USA progress in achieving job guarantees and improved access to information and consultation has depended on the willingness to offer concessions over such matters as wage levels and job controls. The ability of MNEs to frustrate and dilute such provisions is apparent from the conduct and the difficul passage of the Vredling proposals within the European Community.
Third, while the problems of labour in dealing with MNEs have not received the attention they perhaps deserve, there has been a considerable growth of interest in the role of overseas firms in the reform of labour market workings. The principal locus of interest has been Japanese-type practices.

Indeed, one clear trend in the past decade has been the growing importance of labour market effects in the evaluation of the impact of inward investment. For countries like Britain, and within the USA in industries like automobiles, innovative labour practices are now seen by many as perhaps the major benefit of inward investment. The indirect effects of these practices appear to be directly related to their direct effect. That is, the greater the number and size of Japanese investments the more likely are such investments to influence indigenous producers both through the attraction of suppliers and by example. The ability of organised labour to respond to such initiative is not independent of thei adoption. For example, the Japanese emphasis on team working discourages reliance on unions and may lead to a circumvention of their traditional functions. This makes even less likely the probability of concerted union action both nationally or internationally Hence, the growing recognition of the importance of shop-floor contracts worldwide and the dangers of dependency on existing international union structures (McShane, 1988).

Finally, the extent to which such practices will continue to be implemented and their durability is not clear. Already there are signs from the USA of resistance to further concessions within the UAW (Business Week, 1989). Japanese firms are cutting back on employment both at home and overseas (Breathnach, 1989). The growing convergence of experiences as Japan becomes a major exporter of capital and the USA a major host economy, has important implications for labour responses to multinational production. Their complexity and importance suggests the need for much more research in these areas. While ten years ago it was necessary to conclude that organised labour had made litte progress in responding to the challenge of the MNE, this is even more the case at the end of the 1980s. The past ten years has seen a strengthening, not a weakening, of multinational companies. Would that organised labour could say the same.

\section{References}

Ackroyd, S, Burrell, G, Hughes, M, and Whitaker, A (1988) The Japanisation of British industry Industrial relations journal 19(1):11-23.

Bassett, P (1986) Strike free London, Macmillan.

Bradley, K (1980) A comparative analysis of producer cooperatives: some theoretical and empirical implications British journal of industrial relations 18:155-168.

Breathnach, P (1989) Japanese manufacturing investment in the Republic of Ireland Area 21

British business (1988) Mopping up on the cleaning market 1: 22-24.

Buckley, P J, and Enderwick, P (1985) The industrial relations practices of foreign-owned firms in Britain London, Macmillan.

Business week (1989) The UAW rebels teaming up against teamwork 27 March:34-35.

Choy, C L and Jain, H C (1987) Japanese management in Singapore convergence of human resource management practices Asia - Pacific journal of management 4(2):73-89. 
Clarke, K (1987) Quiet revolution in industrial relations attracting investors. Report of an address to employers in Tokyo British business 16:11.

Coates, K (ed) (1978) The right to useful work Nottingham, Spokesman.

Cole, R E, and Deskins, D R (1988) Racial factors in site location and employmen patterns of Japanese auto firms in America California management review 31(1):9-22.

Coyne, J (1986) Divestment by management buy-out: variant and variety. In Coyne, J and Wright, M (eds) Divestment and strategic change Oxford, Philip Allan.

Dicken, P (1987) Japanese penetration of the European automobile industry: the arrival of Nissan in the UK Tijdschrift voor Econ. en Soc. Geographic 78:2.

Dunning, J H (1986) Japanese participation in British industry Beckenham, Croom Helm.

Ehrenreich, B, and Fuentes, A (1981) Life on the global assembly line MS 9(7):52-59.

Enderwick, P (1979) Multinationals and labour: a review of issues and responses Management bibliographies and reviews 5:219-242.

Enderwick, P (1982) How stable is direct foreign investment? Journal of Irish business and administrative research 4:87-97.

Enderwick, P (1985) Multinational business and labour Beckenham, Croom Helm.

Enderwick, P (1988) Multinational enterprises and UK deindustrialisation University of Waikato Mimeo.

Enderwick, P (1989) (ed) Multinational service firms London, Routledge.

Enderwick, P (1990) The large plant in the Northern Ireland economy University of Waikato Mimeo.

Fox, J (1987) Reaching a single union agreement: a case study Employment gazette December.

Franko, L G (1983) The threat of Japanese multinationals Chichester, John Wiley.

Gennard, J (1972) Multinational corporations and British labour: a review of attitudes and responses London, British North American Committee.

Giles, E (1988) The management of change at Xerox. In Miller, C (ed) New frontiers in international business Proceedings of the annual conference of the Academy of International Business (UK) Thames Polytechnic.

Graham, I (1988) Japanisation as mythology Industrial relations journal 19(1):69-75.

ILO (1981) Employment effects of multinational enterprises in developing countries Geneva International Labour Office.

ILO (1984) Safety and health practices of multinational enterprises Geneva International Labour Office.
International Labour Reports (1986) Don't sign here International labour reports 17:19 20.

Izraeli, D N, Banai, M, Zeira, Y (1980) Women executives in MNC subsidiaries California management review 23(1):53-63.

Jain, H C (1985) Industrial relations practices of Japanese multinationals and their subsidiaries in Canada: are they transferable to Canadian firms? Canadian journal of administrative sciences 2 (1).

Jenkins, R (1987) Transational corporations and uneven development London, Methuen.

Kassalow, E M (1988) Concession bargaining: towards new roles for American unions and managers International labour review 127 (5):593-613.

Lamb, H and Percy, S (1987) Working for big mac London, Transnational Information Centre.

Landor, J (1986) Beyond the pail London, Transnational Information Centre.

Latta, G M and Bellace, J R (1983) Making the corporation transparent: prelude to multinational bargaining Columbia journal of world business 18(2):73-80.

Lim, L (1985) Women workers in multinational enterprises in developing countries Geneva UNCTC/ILO International Labour Office.

Linsenmayer, T (1986) Concession bargaining in the United States Labour and society 11(2):207-220.

Matsuura, N (1984) Japanese management and labour relations in US subsidiaries Industrial relations journal 15(4):38-46.

McShane, D (1988) Making the Euro-links International labour reports 25:12.

Millward, N, and Stevens, M (1986) British workplace industrial relations 1980-1984: The DE/ESRC/PSI/ACAS surveys Aldeshot, Gower.

Morris, J (1988) The who, why and where of Japanese manufacturing investment in the UK Industrial relations journal 19(1):31-40.

Northrup, H R, Campbell, D C, and Slowinski, B J (1988) Multinational unionmanagement consultation in Europe: resurgence in the 1980s? International labour review 127(5):525-543.

Pang, K K and Oliver, N (1988) Personnel strategy in eleven Japanese manufacturing companies in the UK Personnel review 17(3):16-21.

Purcell, J, Marginson, P, Edwards, P K, and Sisson, K (1987) The industrial relations practices of multi-plant foreign owned firms Industrial relations journal 18:130-137.

Reitsperger, W D (1986) Japanese management: coping with British industrial relations Journal of management studies 23(1):72-87. 
Rico, L (1987) The new industrial relations: British electricians new-style agreements Industrial and labour relations review 11: 63-78.

Sawers, D (1986) The experience of German and Japanese subsidiaries in Britain Journal of general management 12(1):5-21.

Sethi, S P, Namiki, N, and Swanson, C L (1984) The false promise of the Japanese miracle London, Pitman.

Smith, D (1988) The Japanese example in South West Birmingham Industrial relations journal 19(1):41-50.

Stopford, J, and Dunning, J H (1983) Multinationals: company performance and global trends London, Macmillan.

Turnbull, P (1986) The 'Japanisation' of production and industrial relations at Lucas Electrical Industrial relations journal 17(3):193-206.

United Nations (1983) Transnational corporations in world development: third survey New York United Nations Centre on Transnational Corporations.

Ward, K B (1988) Women in the global economy. In Gutek, B A, Stromberg, A H and Larwood, L (eds) Women and work: an annual review Vol.3. Beverly Hills, Sage Publications.

White, M, and Trevor, M (1983) Under Japanese management London, Heinemann.

Young, S, Hood, N, and Hamill, J (1988) Foreign multinationals and the British economy Beckenham, Croom Helm. 